\title{
At the Margins of Multiculturalism: Assessing Kymlicka's Liberal Multiculturalism in Japan
}

\author{
Kristin Surak \\ School of Oriental and African Studies (SOAS), University of London
}

\begin{abstract}
Will Kymlicka's theories of multiculturalism have gained wide interest in the West, but only recently have been applied beyond it. This research note assesses whether a Kymlickian approach provides traction for grasping the configuration of non-dominant ethnic groupings in Japan and how they have achieved a degree of multicultural recognition. It first identifies equivalents and exceptions within the Japanese case to Kymlicka's key groupings: national minorities, indigenous peoples, immigrants, and metics. It then shows that of these, the last two drove the expansion of multicultural rights. Finally, it examines why they launched claims within a multicultural framework, and assess the limits of the multicultural claims for bolstering the rights of subordinate groups.
\end{abstract}

\section{INTRODUCTION}

Over the past thirty years, multicultural theories, discourses, and claims have become well established in both academic analyses and public debates in the West. Yet they have not remained rooted in their areas of origin. It is perhaps unsurprising that multicultural configurations have been proclaimed in contexts like Russia, Turkey, and Brazil given the history of nation-formation in those countries. ${ }^{1}$ But since the turn of the millennium, a trend almost unimaginable a few decades before has taken hold in the analysis of Japanese society: academics have declared Japan multicultural. In the words of one prominent commentator, "Japan, like it or not, is becoming an increasingly plural society."2

Such claims are bold. Even by the most expansive definitions of ethnic diversity, only $5 \%$ of the population in Japan is non-Japanese. ${ }^{3}$ Yet as the government in the decades following World War II repeatedly denied the existence of any nonJapanese in the country, the bar was set low for asserting that Japan was more diverse than typically thought. Change since then has been slow, and politicians still issue xenophobic statements that would grab headlines in Europe, but go largely unnoticed in the local media. Nonetheless, in recent years the national government has come forward with a set of guidelines for prefectures and municipalities to promote multicultural coexistence. ${ }^{4}$ The result has been a greater recognition of and social 
support for newcomers to the country. ${ }^{5}$ As such, though Japan is descriptively multicultural in limited form, some elements have become prescriptively multicultural. How has this configuration emerged and what has been its impact?

\section{KYMLICKA'S MULTICULTURALISM IN THE WEST AND BEYOND}

Multicultural claims turn on several issues, from intercultural dialogue and identity recognition, to rights of equality and self-government. ${ }^{6}$ Yet common across concerns, according to one of multiculturalism's the most vocal theorists, Will Kymlicka, is a basic grounding in liberal democratic values manifested in a commitment to raceneutral admission and naturalization policies, and to multicultural modes of integration that allow people to freely express their ethnic identities and oblige public institutions to accommodate them. ${ }^{7}$

In an engagement on the prospects of multiculturalism in East Asia, Kymlicka argues that these values have flourished in the West - but not beyond - as a result of five factors. First is demography. Declining birthrates and increased immigration rates have shifted the population balance in the direction of non-dominant groups. Second, the spread of liberal-democratic values since World War II has enabled members of minority groups to demand equality as a fundamental right. Third, democratic forms of rule protect subordinate groups from indiscriminate repression and offer multiple arenas for claims-making. Fourth, post-war peace has reduced the threat that nondominant groups may collaborate with military enemies and removed minority politics from the domain of national security. Finally, a broad acceptance of democracy and human rights has reduced concerns that expanding minority rights will result in "islands of local tyranny" within a state. ${ }^{8}$ The broad array can be condensed into three factors: demographic shifts favoring minorities, the spread of democratic values and structures of rule, and post-war peace. According to Kymlicka, they account for two outcomes: the increased demand for multicultural rights by minority groups, and the diminished reluctance of ruling elites to grant them.

Looking beyond the West, Kymlicka maintains that the absence of these factors stands behind Asia's overall lackluster performance on multicultural issues. The logic of explanation is not only negative, however, and he suggests that multicultural claims have gained limited traction due also to a combination of unwelcoming elements. Members of dominant groups seem largely optimistic that sub-state ethnic divisions will diminish with modernization; that is, they take assimilation for granted. In cases where ethnic boundaries remain strong, the divisions are typically linked to ethnic violence, which render states reluctant to extend rights and privileges due to concerns for security. These two factors hold across multiple types of sub-national groups in Kymlicka's account. Additionally, he notes some group-specific factors that can be found in Asia as well. In the case of indigenous minorities, the ruling elite may see their claims as impeding much needed modernization and economic development. Long-term foreign residents that remain excluded from the polis - Koreans in Japan and "Indian Tamils" in Sri Lanka are his examples - may be regarded as having been wrongly privileged under colonial rule, with the result that now political rights are withheld to counterbalance their accrued economic power. Finally, elites may worry that granting greater regional autonomy will erode liberal democratic rule, which leads them to caution when extending rights to national minorities. ${ }^{9}$ 


\section{THE JAPANESE CASE}

In offering this set of explanations, Kymlicka captures the region in broad strokes, as he is well aware. But does his explanation stand up to the empirical evidence in specific national contexts? Japan is an interesting case to explore because, as Kymlicka himself notes, multicultural discourses have gained traction since the turn of the millennium. If the prime minister in 1986 was able to declare before the National Diet that Japan has no minorities, this was no longer tenable twenty years later. Heralding the transformation was a rash of titles that proclaimed Japan to be far more ethnically diverse than received wisdom. Among them stood John Lie's Multiethnic Japan; Donald Denoon, Mark Hudson, Gavan McCormack and Tessa Morris-Suzuki's Multicultural Japan; Yoneo Ishii and Masayuki Yamauchi's Nihonjin to Tabunkashugi; Mike Douglass and Glenda Roberts's Japan and Global Migration: Foreign Workers and the Advent of a Multicultural Society; and Hiroshi Komai's Tabunka Shakai e no Michi. ${ }^{10}$ These analyses were not without precursors, including foundational studies on resident Koreans, and the myth of the homogeneous nation, as well as those spotlighting Japan's minorities. ${ }^{11}$ But the turn of the millennium marked a discernable shift in how debates were framed as authors began reaching for the language of multiculturalism to capture the ethnic diversity that had long been sidelined. These did not go unnoticed as the media radiated the message outwards and non-governmental organizations pushed for greater awareness. By 2005, the Ministry of Internal Affairs and Communications issued the Plan for the Promotion of Multicultural Community Building intended to encourage "multicultural co-existence" in communities. What drove this shift?

\section{NON-JAPANESE IN JAPAN}

To assess the extent to which Kymlicka's framework accounts for the variation within Japan, we can begin with the subordinated communities to which multicultural commitments apply, and which might press for multicultural rights. For Kymlicka, these can be broken down into four groupings: (1) national minorities, or geographically concentrated cultural groups that conceive of themselves as a distinct nation within a larger state; (2) indigenous peoples, or aboriginal groups who have been stripped of land claims and cultural rights by colonizing settlers; (3) immigrant groups, or people who have chosen to emigrate and are placed on a short track to citizenship; and (4), metics, or foreigners regarded as only temporary inhabitants and not potential citizens. In Walzerian terms, they are the residents, such as asylum seekers, guestworkers, and foreign students, who are excluded from the polis. ${ }^{12}$

Applied to Japan, Kymlicka's categories find several possible analogues. As will be addressed in greater detail below, the Ainu approximate indigenous people, the Okinawans can be seen as a national minority, and the large and diverse population of foreigners, dominated by Chinese, Koreans, and Brazilians, constitute a class of metics and immigrants - albeit a heterogeneous one, whose members possess vastly different legal rights. Kymlicka's rubric reaches its limits, though, in the case of the two to three million Burakumin, members of a former outcaste class who were stigmatized and racialized for undertaking "unclean" jobs in the past, including leatherwork and animal slaughter. They are more geographically dispersed than national minorities and lack the background of settler invasion distinctive to 
indigenous groups. In their case, the logic of exclusion has been formulated in roughly caste terms, and the material basis for claims of a distinct culture, central to Kymlicka's argument, is thin. Indeed, in recent years, the anti-discrimination efforts by their leading organization, the Buraku Liberation League, have stressed the basic sameness of Burakumin and mainstream Japanese over any deep difference sometimes to the chagrin of other subordinated groups. ${ }^{13}$

On this terrain, does the presence and absence of the factors Kymlicka identifies as propelling the expansion of multicultural rights in the West account for the emergence of limited multicultural claims in Japan? To begin with indigenous peoples, the Ainu lend credence to Kymlicka's argument that demographics matter, but in a negative manner. In the late nineteenth century, the Japanese state laid sovereign claim to the large northern island, now known as Hokkaido, populated by a hunter-gatherer population that moved into trading as the Japanese encroached. Colonization and settlement displaced the indigenous Ainu whose numbers deteriorated from a peak of 80,000 through illness, intermarriage, and assimilation. When Tokyo granted them national membership with limited rights in 1899, they lost the possibility to legally claim aboriginal status. ${ }^{14}$ This held until the government passed a non-binding resolution in 2008 that formally recognized their indigeneity. Over the past few decades, the rise of a "new Ainu politics," ${ }^{15}$ fusing identity consciousness and political action, has secured some gains in cultural recognition and native land rights. But with only a mere 25,000 Ainu remaining, according to official accounts, ${ }^{16}$ their small numbers limit the possibility of large-scale social and political transformation based on their causes.

Demographics, however, do not explain why the Okinawans, numbering slightly over one million, have not produced a vigorous multicultural movement for national autonomy. Before its annexation by Japan in 1879, the chain of islands now constituting Okinawa Prefecture stood as a separate Ryūkyū kingdom. Culturally distinct from its two more powerful neighbors, Qing China and Tokugawa Japan, the kingdom negotiated, over the centuries, varying degrees of political autonomy from both. ${ }^{17}$ Self-rule came to an end when Japanese imperial annexation transformed Ryūkyū into Okinawa, and into not only the most distant but also the most destitute prefecture in what would become "naichi," or the inner lands of the empire. With Japanese defeat in 1945, this once self-standing political entity might have made a move for independence, but mobilization for greater autonomy was immediately stymied by the American occupation. The US government took sovereign control over the Okinawa and converted it into a military outpost, and the Okinawans became, effectively, a stateless people. ${ }^{18}$ For them, aligning with Tokyo provided the most effective means to combat the hardships of American rule and the conversion of much prime land into US bases. Across the post-war period, the government in Tokyo continued to press for political control over Okinawa to revert back to Japan, which it gained in 1972, rendering the Okinawans Japanese rather than autonomous Ryūkyūians. ${ }^{19}$ With American military bases still occupying nearly twenty percent of the main island, protest continues daily, but it has brought little momentum towards independence. As such, not the dynamics of liberal democracy, but of imperial politics account for the limits to their claims.

Thus neither the indigenous populations nor the national minorities have been the key targets or the torchbearers of multiculturalism in Japan. The case is different, however, for Kymlicka's other two groupings - immigrants and metics - though his categories must be applied with some care. Strictly speaking, no one is admitted into the Japan as an immigrant; the country's border control regime recognizes only 
temporary entrance. Furthermore, the long-standing foreign populations, including the 400,000 "zainichi" Koreans resident in the country for over three generations, have obtained expansive rights, approaching those of citizens. ${ }^{20}$ As such, the label "metic" is somewhat misplaced in their case. Yet Kymlicka's division captures a key distinction within the diverse group of foreigners in Japan, between the Korean population, present for over 70 years, and the "newcomers" who have arrived over the past two decades, largely from China, Brazil, and the Philippines.

The resident Korean population is the product of Japanese imperial expansion and defeat. When Japan annexed the Korean peninsula in 1910, its population became Japanese nationals of a lesser sort - members of the "gaichi" outer lands, rather than the "naichi" metropole. Wartime labor conscription, however, forced masses of Koreans across the Sea of Japan, their numbers reaching two million by 1945 . At the end of World War II, most but not all returned to their homeland, leaving around 600,000 in the defeated Japan. ${ }^{21}$ Stripped of their Japanese nationality in 1952, they were rendered stateless by the Korean War. While North Korea, consolidating influence throughout the $1950 \mathrm{~s}$ and $60 \mathrm{~s}$, actively sought to repatriate as many as possible to increase its population, South Korea moved to secure permanent residence overseas for those who pledged allegiance to the ROK. The 1965 Treaty on Basic Relations that normalized affairs between Japan and the southern half of the peninsula established this as a right. Within a few years, and following a strong campaign waged by Seoul, roughly half of the Koreans in Japan elected to register as South Korean nationals, generally for pragmatic rather than political reasons. ${ }^{22}$ In the late 1980s, Japan extended special residence rights to all long-standing resident Koreans, even those who did not register with the South Korean government. Furthermore legal reforms granted them privileges nearly equivalent with those of Japanese nationals, with the exception of the franchise at the national level and the right to hold some public offices.

Yet even as some rights were extended, Koreans remained socially excluded from Japanese society and were rarely tempted to assume the nationality of their former colonial oppressors. In the 1950s and 60s, they developed a well-networked community supported by schools, businesses, temples, and civic organizations. ${ }^{23}$ Aid from both Korean governments fostered the growth of "North" and "South" variants of these institutions, and competition between the camps enhanced the allegiances and identities at stake. ${ }^{24}$ Civic organizations, on the whole, did not fight for easy access to Japanese citizenship, for in Japan the equation of citizenship with identity condensed to the formula that all Japanese are citizens of Japan and all citizens of Japan are Japanese - was seen to undermine their membership base. ${ }^{25}$ Nonetheless, demographic change has taken its toll on the community, whose strength has been eroded by high rates of exogamy combined with pressures of linguistic and cultural assimilation. Mixed marriages account over $80 \%$ of unions, and over $90 \%$ attend Japanese schools. ${ }^{26}$ Though continued stigmatization of Koreanness has ensured that they remain a subordinated population, it is not solely the "myth of the homogeneous nation" that preserves the ethnic boundary. ${ }^{27}$ Cold War politics and the interests of community organizations that have made significant contributions to the maintenance of an institutionally complete Korean community, if one divided along north-south lines. As such, the case offers little support for Kymlicka's argument that peace among neighboring countries promotes the extension of multicultural rights. In Japan, relations with South Korea have been normalized, while military tensions still run high with North Korea. Nonetheless, rights in recent years have been extended to long-standing resident Koreans across the board. 


\section{EMERGENCE OF MULTICULTURAL CLAIMS}

Yet these rights were neither claimed nor achieved though references to multiculturalism. The proximate cause behind its rise came from elsewhere: the arrival of a new wave of foreigners. Entering after immigration law reform from 1990 opened several front and side doors, these new arrivals doubled the foreign population over the course of 25 years to just over 2 million. ${ }^{28}$ Though the Chinese are the most numerous today, numbering over 700,000, the Japanese-Brazilians and JapanesePeruvians are the key group of interest due to the special visa rights they enjoy that facilitate long-term settlement.

The Immigration Control Act, which took effect in 1990, granted the descendants of Japanese emigrants through the third-generation indefinitely renewable residence permits with no work restrictions for visits to Japan. Though these were, ostensibly, to enable them to learn about their cultural heritage and visit their ancestors' graves, businesses embraced this new supply of low-skilled workers for undesirable jobs. ${ }^{29}$ By the mid-2000s, their numbers hovered around 300,000. Able to bring their families, these initially temporary migrants often ended up settling in Japan as their children became an anchor in the new community. It was the children, as they entered local schools, that provided the supportive frame for the discourse of multiculturalism, labeled tabunka kyōsei, or "multicultural co-existence," to take hold in Japan.

The term kyōsei - co-existence - was already in use at the time. In academic circles, the neologism moved from biology to pedagogy in the 1970s when it was first used in the effort to develop classrooms where handicapped children could learn alongside their peers. By the late 1980s, it was extended to learning environments where different genders could "co-exist." Thus it was a term educators and civic organizations could reach for in the 1990s when they began to grapple with the challenges posed by a new wave of migrants settling in their locales. ${ }^{30}$ At the time, the multicultural boom was in full swing in North America and Europe, which became sources of inspiration, and by the close of the decade, many educators and nongovernment organization activists with international connections began to speak of a multicultural Japan. These two groups, educators and civic organizations, encouraged the spread of tabunka kyōsei as a discourse loosely organized around the imperative for different cultures to live together in harmony. Though initially its usage was confined to newly arrived foreigners, the term found ready application to the resident Koreans as well. Within a few years, the governments of cities with growing foreign populations - not only Brazilians, but Chinese, Filipinos, and others - began to latch on, using "multicultural coexistence" to frame their integration efforts. By the mid2000 s, even the national government issued a plan for the "promotion of multicultural co-existence" in local communities, encouraging all major cities and prefectures to develop the means for "multicultural community building." 31

Yet a sea change did not follow. In the decade since the unfunded plan was first issued, the national government has done little else to promote a multicultural Japan. Advances remain limited to the local efforts of a few dozen cities and schools with substantial foreign populations. The programs implemented, which largely concern tolerance promotion and multilingualism, typically provide helpful services to foreign residents and their families, but do little to challenge public perceptions. ${ }^{32}$ Critics assert both that they do not go far enough and that they encourage a static 
vision of separate and homogeneous cultures. ${ }^{33}$ As analysts of multicultural endeavors have shown, poorly designed programs can reinforce the stereotypes and structures of oppression they are meant to dismantle. ${ }^{34}$

If implementation raises difficulties, so too do definitions and inclusivity. Multicultural coexistence programs, as they reach out to some, do not reach out to others. In Japan, these schemes have largely addressed issues concerning foreigners rather than ethnic minorities in general; Ainu, Okinawans, and Burakumin have only recently begun to appear in these discourses. Furthermore, within the broader category of foreigners, only a subsection is targeted: those with anchors in local communities, such as third-generation resident Koreans, Japanese-Brazilians raising children in Japan, or Chinese and Southeast Asians who have married Japanese and made a home on the archipelago. The limit is understandable given the municipal base that provides traction for the programs that are funded and implemented by cities. The result, however, is that some of the foreigners in the most difficult circumstances within Japan remain outside their remit. Most notable are the nearly 200,000 trainees and technical interns recruited under the guise of skills transfer who work long hours under sub-standard conditions for less than minimum wages. Over 65 percent are from China, though Vietnam, the Philippines, and Indonesia also send workers, and they labor in textiles, food processing, agriculture, and metalwork for a maximum of three years. The government, which likens the low-paid temporary work program to a "study abroad" scheme, stipulates no absolute limit on the number accepted, but creates a ceiling by constraining the proportion of trainees to no more than five percent of employees in a company. ${ }^{35}$ To their count can be added undocumented foreigners and visa overstayers, whom the government estimates to hover around 60,000, but which are likely to number much higher. ${ }^{36}$ Neither set is easily reached by multicultural policies, though they are some of the most vulnerable non-Japanese in the country. The trainee program has come under repeated criticism by the United Nations High Commissioner for Refugees, and the U.S. Department of State has declared that it amounts to "slavery" or "forced labor" in some cases. ${ }^{37}$ The brokers who traffick temporary workers into the country routinely confiscate passports at the border and charge usurious management fees, while employers extract hundreds of dollars for sub-standard room, board, and clothing costs. ${ }^{38}$ As a result, many trainees and technical interns have little option but to put in long overtime hours or work through holidays. Unsurprisingly, death by overwork is above the national average. ${ }^{39}$ For them, the most pressing problems do not turn on the issues that dominate the multicultural debate - identity and cultural rights - but rather on work conditions and legal status. Furthermore, as the multicultural ambit extends only as far as community membership, the "co-existence" rhetoric fits poorly with those whose residence is temporary or illicit. Debates about whether or not Japan should adopt a multicultural identity or whether multicultural co-existence promotes assimilation or pillorization reach their limit when it comes to addressing the most difficult issues facing a substantial portion of the non-Japanese population.

\section{ASSESSMENT}

What are the implications for the application of Kymlicka's theory of multiculturalism outside the West, and in Japan in particular? His framework usefully proposes where to look for multicultural movements, whether around indigenous, national minority, or foreigners' rights. Yet two of the key factors he identifies as 
driving the expansion of multicultural rights in the West - peaceful relations with neighbors and democratic values and forms of rule - offer less explanatory leverage than the power politics he ignores. Multicultural debates might have developed around indigenous or national minority rights, but demography in the case of the Ainu and American foreign interests in the case of the Okinawans - the latter factor wholly overlooked by Kymlicka - neutralized this possibility. Instead, they emerged around foreigners. These discourses coalesced in the late 1990s as localities with concentrations of newcomers modified western models of multiculturalism in their search for frameworks to deal with the issues raised by foreign populations staying longer than expected. The multicultural co-existence call for mutual respect and tolerance subsequently found reception among the longer-standing foreign community of resident Koreans. Demography does play a role - the number of foreigners in Japan doubled as overall population growth slowed - but numbers alone do not account for the emergence of "multicultural co-existence" as a framing device that spread through pedagogical and international channels.

Still, the extent to which multicultural imperatives are recognized remains limited. The government has done little more than offer white papers, and has left a patchwork of municipalities to develop programs on their own. The factors Kymlicka proposes that might limit the traction of multiculturalism have uneven application. Of them, assumptions among the ruling elite that non-Japanese will eventually assimilate remain strong. The government has periodically cited security concerns when cracking down on resident Koreans, particularly those affiliated with North Korean organizations, but it has rarely, if at all, employed them against the Ainu, Okinawans, or Brazilian-Japanese. Offering less leverage are the group-specific explanations that Kymlicka lays out: concerns that self-rule for national minorities will diminish liberal democracy; worries that rights for indigenous groups will inhibit economic modernization; and beliefs that metics, privileged under colonial rule and wielding economic leverage, should not be unduly favored. None of these hold for the Japanese case. With the third largest economy in the world, economic development and modernization has not been a concern for nearly half a century. The foreigners who came to the country under Japanese colonial rule were more oppressed than privileged. Finally, the erosion of liberal democratic rule in places like Okinawa, where breakaway nationalism is conceivable, has never been a concern. Indeed, when it is thematized in Okinawan protests, it is usually to assert the opposite: that greater regional autonomy is needed to preserve democracy and respect for electoral outcomes against Tokyo's attempts to impose its own military decisions.

If multicultural claims have resulted in gains for some, their extension to others remains limited. Their effectiveness has been restricted to populations with ties of residence to a community. More transient populations of foreigners, such as temporary migrant workers, remain outside their ambit. Indeed, the case of Singapore illustrates that the adoption of a multicultural national self-definition itself does little to address the exploitation of temporary and irregular workers. ${ }^{40}$ As a contribution to normative political theory, Kymlicka's framework is still wanting when it comes to addressing the needs of many ethnic minorities within Japan. Multicultural claims and demands typically carry a bias towards settlement, which can leave many of the worst-off foreigners still at the margins. 
1 On Russia, see Graham Smith, "Russia's Politics of Multicultural Recognition," Peace Review: A Journal of Social Justice 10, no. 2 (2007): 165-71; on Turkey, see Umut Ozkirimli, "Vigilance and Apprehension: Multicultural Democracy and the 'Kurdish Question' in Turkey," Middle East Critique 22, no. 1 (2013): 25-43; on Brazil, see Amos Nascimento, "Syncretism as a Form of Multicultural Politics: Interlocation of African-Latin-American Identities in Brazil," Latin American and Caribbean Ethnic Studies 7, no. 2 (2012): 115-36.

2 John Clammer, Japan and Its Others: Globalization, Difference, and the Critique of Modernity (Melbourne: Trans Pacific Press, 2001), 31. See also examples in David Blake Willis and Stephen Murphy-Shigematsu, Transcultural Japan: At the Borderlands of Race, Gender, and Identity (New York: Routledge, 2008).

3 John Lie, Multiethnic Japan (Cambridge: Harvard University Press, 2001).

${ }^{4}$ See Stephen Robert Nagy, Local Government Migrant Policies in Tokyo, Japan: National Exclusion, Local Inclusion (Lampeter: Edwin Mellen Press, 2013).

${ }^{5}$ Stephen Robert Nagy, "The Advent of Liberal Democratic Multiculturalism? A Case Study of Multicultural Coexistence Policies in Japan," Electronic Journal of Contemporary Japanese Studies 15, no. 1 (2015).

${ }^{6}$ On intercultural dialogue, see Seyla Benhabib, The Claims of Culture: Equality and Diversity in the Global Era (Princeton: Princeton University Press, 2002); on identity recognition, see Charles Taylor, Multiculturalism and "The Politics of Recognition": An Essay (Princeton: Princeton University Press, 1992); on rights of equality, see Bhikhu Parekh, "Equality in a Multicultural Society," Citizenship Studies, 2, no. 3 (1998), 397-411; on self-government, see Will Kymlicka, Multicultural Citizenship: A Liberal Theory of Minority Rights (Oxford: Claredon Press, 1995).

${ }^{7}$ Will Kymlicka, "Liberal Multiculturalism: Western Models, Global Trends, and Asian Debates," in Multiculturalism in Asia, edited by Will Kymlicka and Baogang He (Oxford: Oxford University Press, 2005), 22-55. See also Will Kymlica, Multicultural Citizenship (Oxford: Oxford University Press, 1995).

${ }^{8}$ Ibid.

${ }^{9}$ Ibid.

${ }^{10}$ John Lie, Multiethnic Japan (Cambridge, MA: Harvard University Press, 2001); Donald Denoon, Mark Hudson, Gavan McCormack and Tessa Morris-Suzuki, editors, Multicultural Japan: Paleolithic to Postmodern (Cambridge: Cambridge University Press, 2001); Yoneo Ishii and Masayuki Yamaguchi, Nihonjin to Tabunkashugi (Tokyo: Hatsubai Yamakawa Shuppansha, 1999); Mike Douglass and Glenda Roberts, editors, Japan and Global Migration: Foreign Workers and the Advent of a Multicultural Society (Honolulu: University of Hawai'i Press, 2003); and Hiroshi Komai, Tabunka Shakai e no Michi (Tokyo: Akashi Shoten, 2003).

${ }^{11}$ On Koreans, see Yasuaki Ōnuma, Tan'itsu Minzoku Shakai no Shinwa o Koete: Zainichi Kankoku Chōsenjin to Shutsu'nyūkoku Kanri Taisei (Tokyo: Tōshindō, 1986); Sonia Ryang, North Koreans in Japan: Language, Ideology, and Identity (Boulder: Westview Press, 1997). On the myth of the homogenous nation, see Hideichirō Nakano und Kōjirō Imazu, editors, Esunishiti no Shakaigaku: Nihon Shakai no Mizokuteki Kōsei (Kyoto: Seki Shisōsha, 1993); Eiji Oguma, Tan'itsu Minzoku Shinwa no Kigen: "Nihonjin” no Jigazō no Keifu (Tokyo: Shin'yōsha, 1995). On minorities, see Michael Weiner, Japan's Minorities: The Illusion of Homogeneity (London: Routledge, 1997). 
${ }^{12}$ Kymlicka, "Liberal Multiculturalism."

13 John H. Davis, "Blurring the Boundaries of the Buraku(min)," in Globalization and Social Change in Contemporary Japan, edited by J. S. Eades, Tom Gill, Harumi Befu (Melbourne: Trans Pacific Press, 2000), 110-122.

${ }^{14}$ Toshimitsu Miyajima, Ainu Minzoku to Nihon no Rekishi: Senjūminzoku no Kunan, Teikō, Fukken (Tokyo: San'ichi Shobō, 1996).

15 Richard Siddle, Race, Resistance, and the Ainu of Japan (London: Routledge, 1996).

${ }^{16}$ Hokkaidō Kankyō Seikatsubu, Hokkaidō Ainu Seikatsu Jittai Chōsa (2006) http://www.pref.hokkaido.lg.jp/ks/ass/grp/H18houkokusyo.pdf

${ }^{17}$ Koji Taira, "Troubled National Identity: The Ryukyuans/Okinawans," Japan's Minorities: The Illusion of Homogeneity, edited by Michael Weiner (London: Routledge, 1997), 140-177.

${ }^{18}$ Chalmers Johnson, Okinawa: Cold War Island (Cardiff: Japan Policy Research Institute, 1999).

${ }^{19}$ Taira, "Troubled National Identity."

${ }^{20}$ cf. Kymlicka, "Liberal Multiculturalism," 52.

${ }^{21}$ Approximately 30,000 Taiwanese remained as well. On repatriation and cross-border movements between Japan and the Korean peninsula, see Tessa MorrisSuzuki, "Immigration and Citizenship in Contemporary Japan" in Japan: Continuity and Change, edited by Javed Maswood, Jeffrey Graham and Hideaki Miyajima (London: Routledge Curzon, 2002), 163-178.

${ }^{22}$ Rogers Brubaker and Jaeeun Kim, "Transborder Membership Politics in Germany and Korea," European Journal of Sociology 52 (2011): 21-75.

${ }^{23}$ Sonia Ryang, North Koreans in Japan: Language, Ideology, and Identity (Boulder: Westview Press, 1997).

${ }^{24}$ Brubaker and Kim, "Transborder Membership Politics."

25 Erin A. Chung, Immigration and Citizenship in Japan (New York: Cambridge University Press, 2010).

${ }^{26}$ Kaori Okano, "Ethnic Koreans in Japanese Schools: Shifting Boundaries and Collaboration with Other Groups," in Minorities and Education in Multicultural Japan: An Interactive Perspective, edited by Kaori Okano, Ryoko Tsuneyoshi and Sarane Spence Boocock (Abingdon: Routledge, 2011), 100-126.

${ }^{27}$ Eiji Oguma popularized this term in a best seller. Oguma, Tan'itsu Minzoku.

${ }^{28}$ Ministry of Justice, Immigration Control Report (Tokyo: Ministry of Justice, 2014).

${ }^{29}$ Takamichi Kajita, "Nihon no Gaikokujin Rōdōsha Seisaku," in Kokusaika Suru Nihon Shakai, edited by Takamichi Kajita and Takashi Miyajima (Tokyo: Tokyo University Press, 2002), 15-44.

${ }^{30}$ See Kōsei Sakuma. Gaikokujin no Kodomo no Kyōiku Mondai: Seifunai Kondankai ni okeru Teigen (Tokyo: Keisōshobō, 2011).

31 Chikako Kashiwazaki, "Incorporating Immigrants as Foreigners: Multicultural Politics in Japan.” Citizenship Studies 17, no. 1 (2013): 31-47; Nagy, "Advent of Liberal Democratic Multiculturalism?"

${ }^{32}$ See Nagy, Local Government Migrant Policies.

33 Tessa Morris-Suzuki, "Immigration and Citizenship in Contemporary Japan" in Japan: Continuity and Change, edited by Javed Maswood, Jeffrey Graham and Hideaki Miyajima (London: Routledge Curzon, 2002),163-178; Misako Nukaga, Misako, "Japanese Education in an Era of Internationalization: A Case Study of an 
Emerging Multicultural Coexistence Model," International Journal of Japanese Sociology, 12, no. 1 (2003): 79-94; Chris Burgess, "Celebrating 'Multicultural Japan': Writings on 'Minorities' and the Discourse on 'Difference'," Electronic Journal of Contemporary Japanese Studies 8, no. 2 (2008); Kashiwazaki, "Incorporating Immigrants."

34 Ghassan Hage, White Nation: Fantasies of White Supremacy in a Multicultural Society (New York: Routledge, 1999); Chris Burgess, "Maintaining Identities: Discourses of Homogeneity in a Rapidly Globalizing Japan," Electronic Journal of Contemporary Japanese Studies 4, no. 1 (2004); Nukaga, "Japanese Education."

${ }^{35}$ See Kristin Surak, "Migration Industries and the State: Guestwork Programs in East Asia," International Migration Review (forthcoming).

${ }^{36}$ Ministry of Justice, Immigration Control Report.

${ }^{37}$ U.S. Department of State, Trafficking in Persons Report (Washington DC: U.S. Department of State, 2007); U.S. Department of State, Trafficking in Persons Report (Washington D.C.: U.S. Department of State, 2014); Jorge Bustamante, Report of the Special Rapporteur on the Human Rights of Migrants: Annex (Human Rights Council, Seventeenth Session of the United Nations General Assembly, 2011).

38 Daniele Belanger, Kayoko Ueno, Khuat Thu Hong, and Emiko Ochiai, "From Foreign Trainees to Unauthorized Workers: Vietnamese Migrant Workers in Japan," Asia Pacific Migration Journal 20, no. 1 (2011), 31-53; Chizuko Hayakawa, "Gaikokujin Kenshū Ginō/Jisshū Seidō ni okeru Rōdōhō no Teikyō Mondai." Nihon Rōdōhō Gakushi 112 (2008): 73-81.

${ }^{39}$ Gaikokujin Kenshūsei Mondai Nettowaaku, editors, Gaikokujin Kenshūsei: Jikyū 300en no Rōdōsha, Vol. 1 (Tokyo: Akashi Shoten, 2006); Gaikokujin Kenshūsei Mondai Nettowaaku, editors, Gaikokujin Kenshūsei: Jikyū 300en no Rōdōsha, Vol. 2 (Tokyo: Akashi Shoten, 2009); Belanger et al., "From Foreign Trainees"; Kōichi Yasuda, "Gaikokujin Jisshūseidō no Jitai to Kaisei Nyūhōgo no Genjō wo Kokuhatsu Suru," in Gaikokujin Jisshūsei: Sabetsu, Yokuatsu, Sakushu no Shisutemu. Tokyo: Gakushū no Tomosha, 2013), 24-63.

${ }^{40}$ Theresa Devasahayam, Theresa, "Placement and/or Protection? Singapore's Labour Policies and Practices for Temporary Women Migrant Workers." Journal of Asia Pacific Economy, 15, no. 1 (2010): 45-58; Charanpal Bal, "Production Politics and Migrant Labor Advocacy in Singapore." Journal of Contemporary Asia 45, no. 2 (2014): 219-242.

Kristin Surak is an Associate Professor of Politics at the School of Oriental and African Studies (SOAS), University of London and a past Richard B. Fisher Member of the Institute for Advanced Study, Princeton. Her research on international migration, nationalism, culture, and political sociology has appeared in leading academic and intellectual journals, including the European Journal of Sociology, International Migration Review, and the London Review of Books, and her work has been translated into Japanese, Spanish, Swedish, German, and Korean. In 2014, she received the Book of the Year Award from the American Sociological Association's Asia Section for Making Tea, Making Japan: Cultural Nationalism in Practice (Stanford University Press). 